\title{
BRIDGES DEFECTS AND MAINTENANCE STRATEGIES IN EGYPT
}

\author{
Mohamed Hanafy Mahmoud Abd Al Wahab, Ahmed A. Mohammady \\ and Ashraf EI Shahat \\ Zagazig University, Faculty of Engineering - Construction and utilities department
}

\begin{abstract}
A significant difference between essential and preventive maintenance is that essential maintenance is normally undertaken when the bridge reliability has fallen to or below the target value while preventive maintenance is undertaken when the bridge reliability is still above the target value. This paper aims to know and identify the main and minor defects in the bridge in Egypt in order to prepare corrective plan to solve these defects in preventive stage. A sample of bridges distributed overall Egypt and had different conditions will be chosen, studied and analyzed. The sample includes 45 bridge and its maintenance reports. The end result of this paper will be a general reliability -based framework to be used by General Authority for Roads \& Bridges and Transportation in Egypt in order to plan optimal strategies for the maintenance of its bridge network.
\end{abstract}

\section{1- INTRODUCTION:}

Bridges are essential infrastructure of the transportation network. Therefore, maintenance tasks are mandatory to prevent these structures from degradation overtime. (Cheng \& Hoang [1]). As the existing tasks of bridges continue to deteriorate, many countries have to deal with the ever increasing demands on the limited resources available for their maintenance. (Das [2]). The maintenance planning find a balance between obtained because the planning horizon spans amount of uncertainty is inherent-rating process and the cost actions (Yang et al. [3]).

The function of the road is to provide a safe, economical and effective road network for the movement of people and goods. And an effective bridge management strategy is very important in fulfilling this function. In terms of the demand of current operation and management of the existing highway bridges (Shan \& Li [4]). Timely and adequate maintenance interventions are therefore crucial to ensure the functionality of existing bridges in a network. Under budget constraints, it is important to priorize maintenance needs bridges that are most significant to the functionality of the entire network. (Liu \& Frangopol [5]). Bridge risk assessment often serves as the basis for bridge maintenance priority ranking and optimization and conducted periodically (Elag \& Wang [6]).

\section{2- $\quad$ Statistical Data:}

Bridge statistics were collected from General Authority for Roads \& Bridges and Transportation (GARBT [7]). Chart [1] presents the distribution of the bridges over all Egypt. 


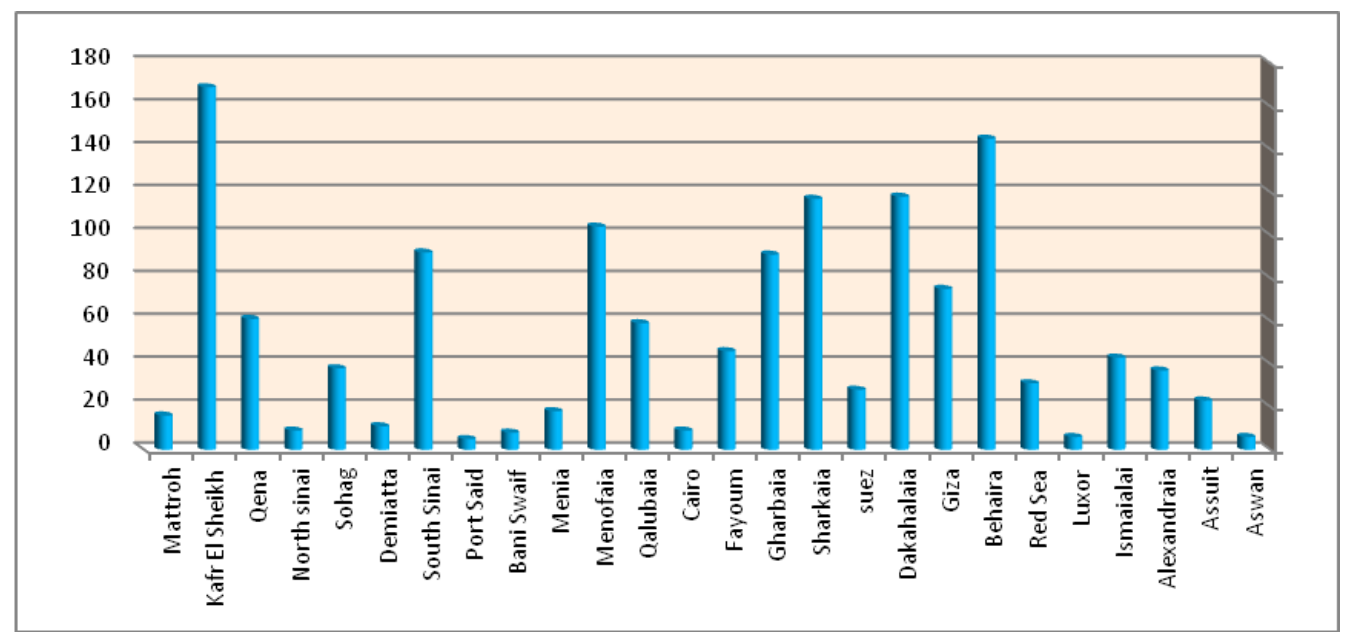

Chart [1] Bridges distribution in Egypt according to governorate

These bridges include all types of bridges fixed, movable, culverts and people bridges. This paper will classified the bridges according to the constructed year as shown in chart [2].

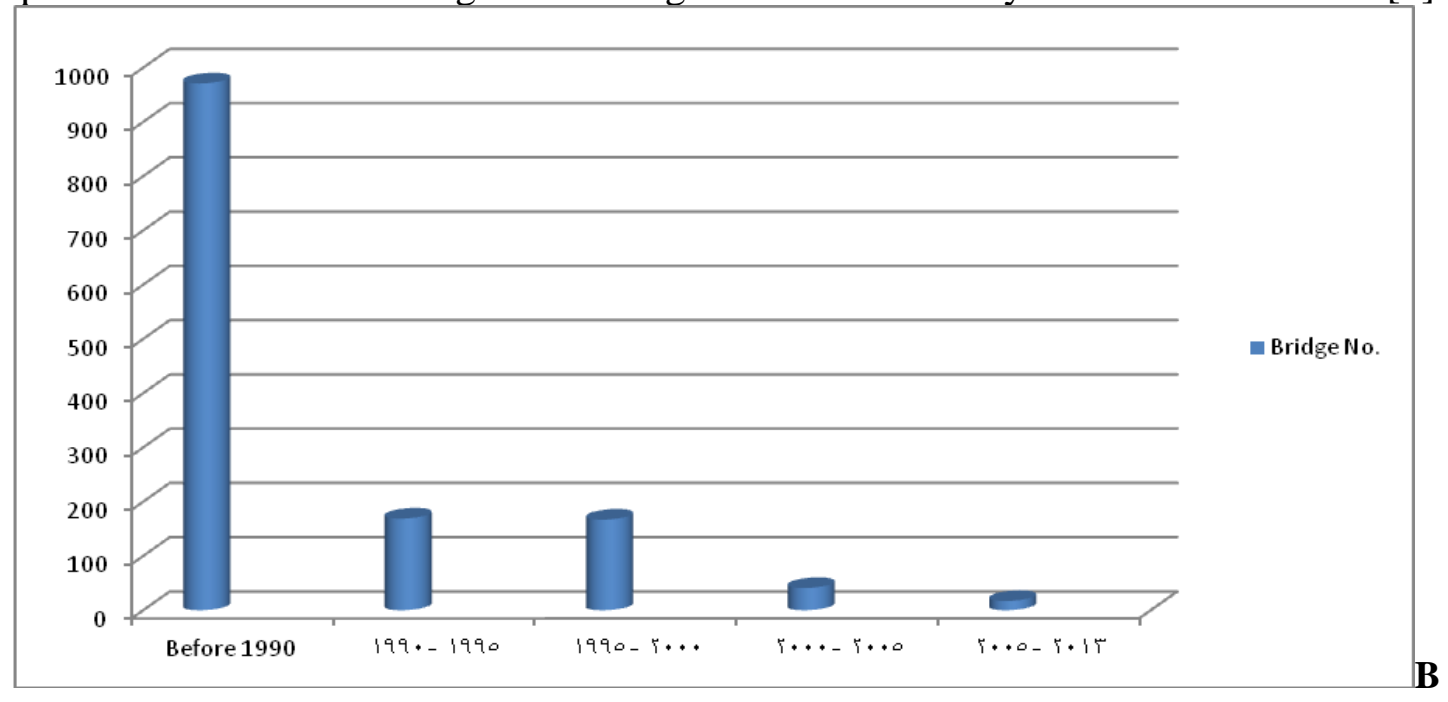

Chart [2] Bridges distribution in Egypt according to constructed year

\section{ridges sample}

In order to know the current status for bridges maintenance in Egypt, this paper will introduce a sample of 45 bridges was selected from (GARBL [7]) inspection reports archive. The bridges in the sample had selected after meetings and discussions with bridge expertise, the sample size was calculated according to the following formula (WEBSITES [8])

Where:

$$
\text { Sample Size }=\frac{\frac{z^{2} \times p(1-p)}{e^{2}}}{1+\left(\frac{z^{2} \times p(1-p)}{e^{2} N}\right)}
$$

(WEBSITES [8])

$\mathrm{Z}:$ it is the number of standard deviations a given proportion is away from the mean. (1.28)

p: percentage picking a choice expressed in decimal (0.9) 
e: Margin of error (5\%)

$\mathrm{N}$ : the total number of the bridges.(1003)

The bridges in the sample will be showed in Table [1]. The sample covers all governorates in Egypt.

Table [1] Bridges sample data

\begin{tabular}{|c|c|c|c|c|}
\hline S.N. & Bridge Name & Location & Bridge Description & $\begin{array}{l}\text { Inspection } \\
\text { Date }\end{array}$ \\
\hline 1 & $\begin{array}{l}\text { Zefta Bridge on rail } \\
\text { way }\end{array}$ & Zefta & $\begin{array}{l}\text { High bridge rested on two } \\
\text { side wall - three spans }\end{array}$ & 20-11-2013 \\
\hline 2 & $\begin{array}{l}\text { Zefta - Met Ghamr } \\
\text { Bridge }\end{array}$ & Zefta & $\begin{array}{l}\text { High bridge, slab system \& } \\
\text { beams rested on columns }\end{array}$ & $28-1-2014$ \\
\hline 3 & Metobas Bridge & Kafr El Shikh & $\begin{array}{l}\text { High bridge, slab system \& } \\
\text { beams rested on columns }\end{array}$ & $27-1-2014$ \\
\hline 4 & Usef sea Bridge & Bani Swaif & $\begin{array}{l}\text { Reinforced concrete and } \\
\text { spans } 20-24 \mathrm{~m} \text { and steel span } \\
\text { over the sea }\end{array}$ & $23-12-2013$ \\
\hline 5 & Hassan Wasef Bridge & Bani Swaif & $\begin{array}{l}\text { Reinforced concrete and } \\
\text { spans } 20 \mathrm{~m} \text { and steel span } \\
\text { over the sea }\end{array}$ & $23-12-2013$ \\
\hline 6 & $\begin{array}{l}\text { High Assuit Bridge (on } \\
\text { the Nile) }\end{array}$ & Assuit & $\begin{array}{l}\text { Reinforced concrete and } \\
\text { spans } 25-30 \mathrm{~m}\end{array}$ & $1-11-2013$ \\
\hline 7 & Menia Sandoub Bridge & $\begin{array}{l}\text { Suez Canal } \\
\text { Area }\end{array}$ & $\begin{array}{l}\text { Reinforced concrete, slab } \\
\text { and beams system rested on } \\
\text { piles. }\end{array}$ & $10-1-2013$ \\
\hline 8 & El Mansoura Bridge & Mansoura & $\begin{array}{l}\text { High bridge, slab system \& } \\
\text { beams rested on columns }\end{array}$ & $20-1-013$ \\
\hline 9 & El Wasafaia Bridge & $\begin{array}{l}\text { Ismailia-Cairo } \\
\text { Road }\end{array}$ & $\begin{array}{l}\text { High bridge, slab system \& } \\
\text { beams rested on columns }\end{array}$ & $25-2-2013$ \\
\hline 10 & Nabaroua Bridge & Dakahlaia & $\begin{array}{l}\text { High bridge, slab system \& } \\
\text { beams rested on columns }\end{array}$ & $11-1-2014$ \\
\hline 11 & Sakr sons Bridge & $\begin{array}{l}\text { Canal / Sinai } \\
\text { Area }\end{array}$ & $\begin{array}{l}\text { Reinforced concrete, three } \\
\text { spans, slab and beams } \\
\text { system rested on piles. }\end{array}$ & $25-2-2013$ \\
\hline 12 & Sawy Bridge & $\begin{array}{r}\text { Canal / Sinai } \\
\text { Area }\end{array}$ & $\begin{array}{l}\text { Reinforced concrete, three } \\
\text { spans, slab and beams } \\
\text { system rested on piles. }\end{array}$ & $27-2-2013$ \\
\hline 13 & Oil factory Bridge & $\begin{array}{r}\text { Canal / Sinai } \\
\text { Area }\end{array}$ & $\begin{array}{l}\text { Reinforced concrete, three } \\
\text { spans, slab and beams } \\
\text { system rested on piles. }\end{array}$ & $27-2-2013$ \\
\hline 14 & Badawy Bridge & $\begin{array}{r}\text { Canal / Sinai } \\
\text { Area }\end{array}$ & $\begin{array}{l}\text { Reinforced concrete, three } \\
\text { spans, slab and beams } \\
\text { system rested on piles. }\end{array}$ & $2-3-2013$ \\
\hline 15 & $\begin{array}{l}\text { El Khadarawaya canal } \\
\text { Bridge }\end{array}$ & $\begin{array}{l}\text { Banah / Kafr El } \\
\text { Zayat Road }\end{array}$ & $\begin{array}{l}\text { Surface bridge, beam and } \\
\text { slab system }\end{array}$ & $5-1-2012$ \\
\hline 16 & Saif Sea Canal Bridge & $\begin{array}{l}\text { Banah / Kafr El } \\
\text { Zayat Road }\end{array}$ & $\begin{array}{l}\text { Surface bridge, beam and } \\
\text { slab system }\end{array}$ & $5-1-2012$ \\
\hline 17 & Tanta Bridge & $\begin{array}{l}\text { Banah / Kafr El } \\
\text { Zayat Road }\end{array}$ & $\begin{array}{l}\text { High bridge, Statically } \\
\text { system is main beams, } \\
\text { secondary beams and slabs. }\end{array}$ & $5-1-2012$ \\
\hline 18 & Toukh Bridge & $\begin{array}{l}\text { Banah / Kafr El } \\
\text { Zayat Road }\end{array}$ & $\begin{array}{l}\text { Surface bridge, beam and } \\
\text { slab system }\end{array}$ & $8-1-2012$ \\
\hline 19 & Kased canal Bridge & $\begin{array}{l}\text { Banah / Kafr El } \\
\text { Zayat Road }\end{array}$ & $\begin{array}{l}\text { Surface over canal and has } \\
\text { three openings. Beam system }\end{array}$ & $8-1-2012$ \\
\hline 20 & Qewasana Bridge & $\begin{array}{l}\text { Banah / Kafr El } \\
\text { Zayat Road }\end{array}$ & $\begin{array}{l}\text { High bridge, Slabs rested on } \\
\text { main beams and secondary } \\
\text { beams. }\end{array}$ & $8-1-2012$ \\
\hline
\end{tabular}




\begin{tabular}{|c|c|c|c|c|}
\hline 21 & Attfa drainage Bridge & $\begin{array}{l}\text { Banah / Kafr El } \\
\text { Zayat Road }\end{array}$ & Surface bridge, Slab type & $8-1-2012$ \\
\hline 22 & EL Khatatba Bridge & $\begin{array}{l}\text { Manashi / } \\
\text { Khatatba Road }\end{array}$ & $\begin{array}{l}\text { High bridge, seven concrete } \\
\text { spans, Slabs rested on main } \\
\text { and secondary beams and } \\
\text { piles }\end{array}$ & $10-12-2011$ \\
\hline 23 & El Tayraya Bridge & $\begin{array}{l}\text { Manashi / } \\
\text { Khatatba Road }\end{array}$ & $\begin{array}{l}\text { High bridge, seven concrete } \\
\text { spans, Slabs rested on main } \\
\text { and secondary beams and } \\
\text { piles }\end{array}$ & $10-12-2011$ \\
\hline 24 & Kafr Dawood Bridge & $\begin{array}{l}\text { Manashi / } \\
\text { Khatatba Road }\end{array}$ & $\begin{array}{l}\text { High bridge, seven concrete } \\
\text { spans, Slabs rested on main } \\
\text { and secondary beams and } \\
\text { piles }\end{array}$ & $15-12-2011$ \\
\hline 25 & $\begin{array}{l}\text { Kafr Dawood Bridge } \\
\text { (surface) }\end{array}$ & $\begin{array}{l}\text { Manashi / } \\
\text { Khatatba Road }\end{array}$ & $\begin{array}{l}\text { Surface Bridge, has three } \\
\text { opening reinforced concrete } \\
\text { and the middle is steel. Slabs } \\
\text { rested on main and } \\
\text { secondary beams }\end{array}$ & $15-12-2011$ \\
\hline 26 & Bollen Bridge & $\begin{array}{l}\text { Manashi / } \\
\text { Khatatba Road }\end{array}$ & $\begin{array}{l}\text { High bridge, has three } \\
\text { opening, Slabs rested on } \\
\text { main and secondary beams }\end{array}$ & $15-12-2011$ \\
\hline 27 & $\begin{array}{l}\text { High bridge at Kafr } \\
\text { Dawood }\end{array}$ & $\begin{array}{l}\text { Middle and } \\
\text { West Delta }\end{array}$ & $\begin{array}{l}\text { Reinforced concrete bridge. } \\
\text { Slabs rested on main beams } \\
\text { and secondary beams and } \\
\text { piles. }\end{array}$ & $20-5-2012$ \\
\hline 28 & Lanch Bridge & Port Said & $\begin{array}{l}\text { Steel structures bridge, span } \\
20-30 \mathrm{~m}\end{array}$ & $11-7-2011$ \\
\hline 29 & Canal two Bridge & Port Said & $\begin{array}{l}\text { Concrete spans, Slab and } \\
\text { beams rested on piles. }\end{array}$ & $15-7-2011$ \\
\hline 30 & Old El Adwa Bridge & El Menia & $\begin{array}{l}\text { Six spans reinforced } \\
\text { concrete and one steel span }\end{array}$ & $10-3-2010$ \\
\hline 31 & Kom Ombo Bridge & Aswan & $\begin{array}{l}14 \text { concrete spans, Box } \\
\text { section and one steel span }\end{array}$ & $8-4-2010$ \\
\hline 32 & Luxor Airport Bridge & Luxor & $\begin{array}{l}\text { Eight concrete spans and one } \\
\text { steel span over the railway. }\end{array}$ & $23-4-2011$ \\
\hline 33 & $\begin{array}{l}\text { Desouk Bridge over } \\
\text { railway }\end{array}$ & $\begin{array}{l}\text { South / West } \\
\text { Delta }\end{array}$ & $\begin{array}{l}\text { High Bridge over railway, } \\
\text { Slabs rested on main \& } \\
\text { secondary beams\& columns }\end{array}$ & $12-1-2012$ \\
\hline 34 & $\begin{array}{l}\text { Desouk Bridge over } \\
\text { Nile }\end{array}$ & $\begin{array}{l}\text { South / } \\
\cdots \cdots . . \cdots \cdots \cdot \ldots \text { W } \\
\text { est Delta }\end{array}$ & $\begin{array}{l}\text { High Bridge, Box section } \\
\text { over Nile }\end{array}$ & $12-1-2012$ \\
\hline 35 & South Sea Bridge & $\begin{array}{l}\text { South / West } \\
\text { Delta }\end{array}$ & $\begin{array}{l}\text { One steel span rested on } \\
\text { concrete foundation and } \\
\text { piles }\end{array}$ & $20-1-2012$ \\
\hline 36 & El Shabasaia Bridge & $\begin{array}{l}\text { South / West } \\
\text { Delta }\end{array}$ & $\begin{array}{l}\text { One span from reinforced } \\
\text { concrete. }\end{array}$ & $20-1-2012$ \\
\hline 37 & $\begin{array}{l}\text { El Awalaui drainage } \\
\text { Bridge }\end{array}$ & $\begin{array}{l}\text { South / West } \\
\text { Delta }\end{array}$ & $\begin{array}{l}\text { One span from reinforced } \\
\text { concrete. }\end{array}$ & $26-1-2012$ \\
\hline 38 & Agamaia Bridge & $\begin{array}{l}\text { South / West } \\
\text { Delta }\end{array}$ & $\begin{array}{l}\text { One span from reinforced } \\
\text { concrete. }\end{array}$ & 26-1-2012 \\
\hline 39 & El Farodous Bridge & Canal / Sinai & $\begin{array}{l}\text { Concrete spans simple, } \\
\text { Slabs rested on beams }\end{array}$ & $18-12-2011$ \\
\hline 40 & Tanata- Bassun Bridge & Tanta & $\begin{array}{l}\text { One span from reinforced } \\
\text { concrete. }\end{array}$ & $10-8-2010$ \\
\hline
\end{tabular}




\begin{tabular}{|l|l|l|l|l|}
\hline 41 & $\begin{array}{l}\text { Nashard drainage } \\
\text { Bridge }\end{array}$ & Tanta & $\begin{array}{l}\text { Concrete slabs rested on } \\
\text { beams }\end{array}$ & $18-8-2010$ \\
\hline 42 & $\begin{array}{l}\text { Batanawaia canal } \\
\text { Bridge }\end{array}$ & Tanta & $\begin{array}{l}\text { Concrete slabs rested on } \\
\text { beams }\end{array}$ & $18-8-2010$ \\
\hline Bridge & $\begin{array}{l}\text { Port Said / } \\
\text { Demiatta Road }\end{array}$ & $\begin{array}{l}\text { Six spans, Concrete slabs } \\
\text { rested on beams and } \\
\text { columns rested on concrete } \\
\text { foundation and piles }\end{array}$ & $28-10-2011$ \\
\hline 44 & El Sadat Bridge & Bani Swaif & $\begin{array}{l}\text { Concrete slabs and steel } \\
\text { slabs over railway }\end{array}$ & $15-10-2011$ \\
\hline 45 & Kilo 4.5 Bridge & $\begin{array}{l}\text { Ismalaya/ Port } \\
\text { Said Road }\end{array}$ & $\begin{array}{l}\text { Six spans, Concrete slabs } \\
\text { rested on beams and } \\
\text { columns rested on concrete } \\
\text { foundation and piles }\end{array}$ & $20-11-2011$ \\
\hline
\end{tabular}

\section{3- Data analysis:}

After collecting the inspection reports, bridge defects will be classified according to the structural element as shown in chart [3] and it shows the percentage of the defects that was found.

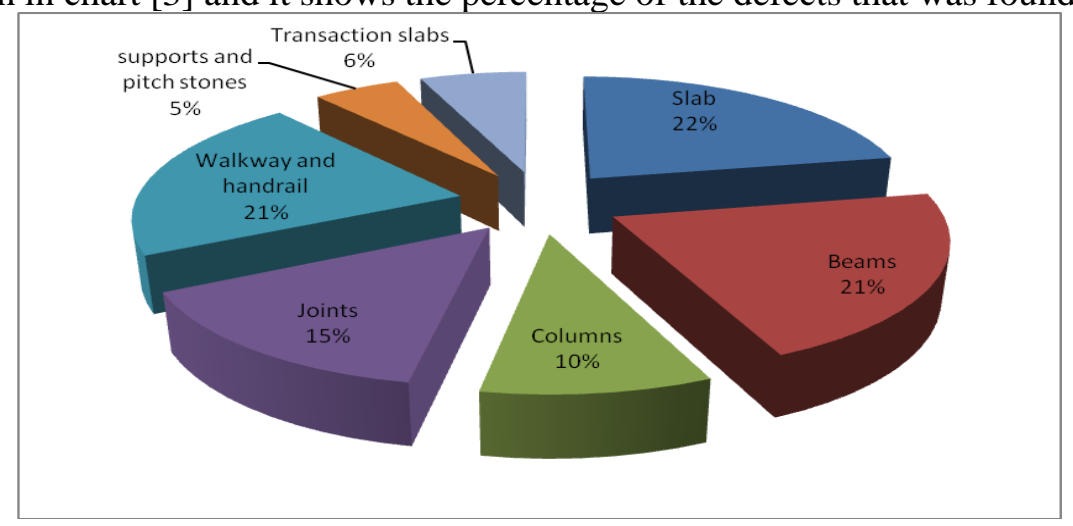

Chart [3] Bridge defects per structural element

It was clear that majority of defects concentrated in slabs, beams and walkways and handrails. The defects in joints had $15 \%$ of the bridges sample. Also columns defect was $10 \%$ of the sample. The defects in transaction slab had $6 \%$ of the bridges sample. Also supports and side pitch stones defect was $5 \%$ of the sample.

Slabs defects detailed in Table [2] and Chart [4]. The majority of defects in slabs are appearance steel bars and voids in slabs. That will cause rust in the steel bars and on the long term will decrease the strength of the reinforced concrete cross section. The lowest defects in slabs were the weakness of the concrete strength and steel bars in the cross section.

Table [2] Slabs defects in the bridges sample

\begin{tabular}{|l|l|l|}
\hline S.N. & Defect Type & $\begin{array}{l}\text { Frequency } \\
\text { percentage } \\
(\%)\end{array}$ \\
\hline 1 & Voids and cavities in slabs & 24.45 \\
\hline 2 & Cracks in slabs & 11.11 \\
\hline 3 & Downfall parts of the concrete slabs & 17.78 \\
\hline 4 & Appearance steel bars in the slabs & 24.45 \\
\hline 5 & Rust in steel bars & 13.33 \\
\hline 6 & No concrete cover & 24.45 \\
\hline 7 & Weakness in rebar and concrete strength & 6.67 \\
\hline 8 & Separation in transaction slab & 8.89 \\
\hline
\end{tabular}




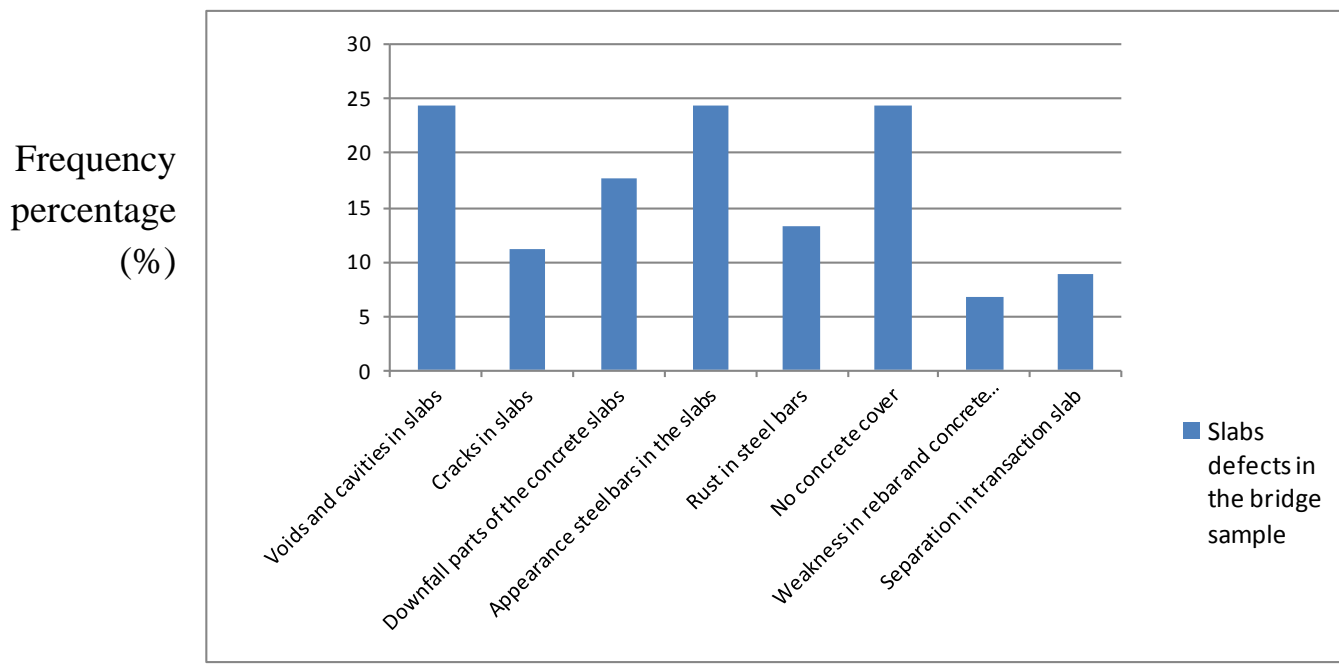

Chart [4] Slabs defects in the bridge sample

Beams defects detailed in Table [3] and Chart [5]. The majority of defects in beams are appearance rebar and voids in beams. That will cause rust in the steel bars and on long term will decrease the strength of the reinforced concrete cross section. The lowest defects in beams were the weakness of the concrete strength and steel bars in the cross section.

Table [3] Beams defects in the bridges sample

\begin{tabular}{|l|l|l|}
\hline S.N. & Defect Type & $\begin{array}{l}\text { Frequency } \\
\text { percentage } \\
(\%)\end{array}$ \\
\hline 1 & Voids and cavities in beams & 31.11 \\
\hline 2 & Cracks in beams & 11.11 \\
\hline 3 & Downfall parts of the concrete & 6.67 \\
\hline 4 & Appearance steel bars & 28.89 \\
\hline 5 & Rust in steel bars & 15.56 \\
\hline 6 & No concrete cover & 22.22 \\
\hline 7 & Weakness in rebar and concrete strength & 6.67 \\
\hline
\end{tabular}

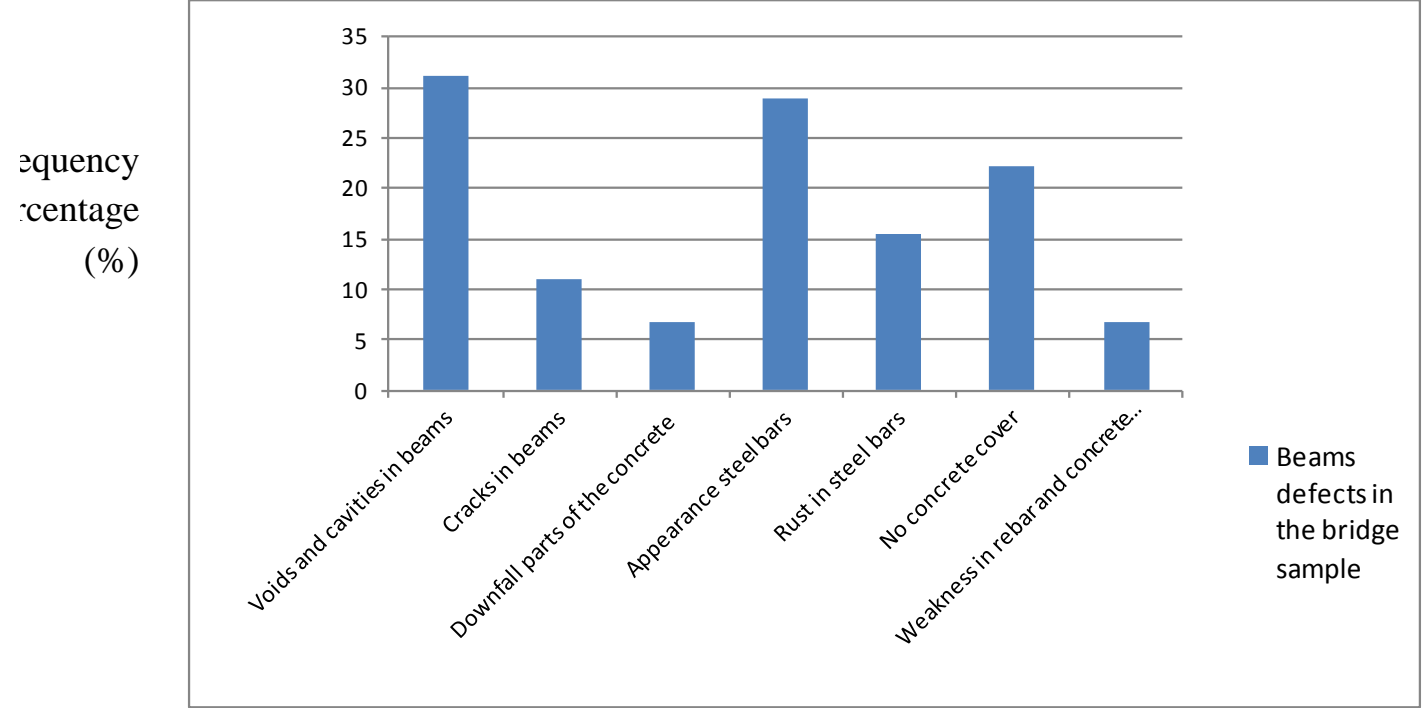

Chart [5] Beams defects in the bridge sample 
Columns defects detailed in Table [4] and Chart [6]. The majority of defects in columns are voids in columns, appearance rebar and cracks in the columns. That will cause rust in the steel bars and on long term will decrease the strength of the reinforced concrete cross section. The lowest defects in columns were the weakness of the concrete strength and steel bars in the cross section.

Table [4] Columns defects in the bridges sample

\begin{tabular}{|l|l|l|}
\hline S.N. & Defect Type & $\begin{array}{l}\text { Frequency } \\
\text { percentage } \\
(\%)\end{array}$ \\
\hline 1 & Voids and cavities in columns & 11.11 \\
\hline 2 & Cracks in columns & 8.89 \\
\hline 3 & Appearance steel bars & 8.89 \\
\hline 3 & Rust in steel bars & 6.67 \\
\hline 5 & No concrete cover & 8.89 \\
\hline 6 & Weakness in rebar and concrete strength & 4.44 \\
\hline
\end{tabular}

Chart [6] Columns defects in the bridge sample

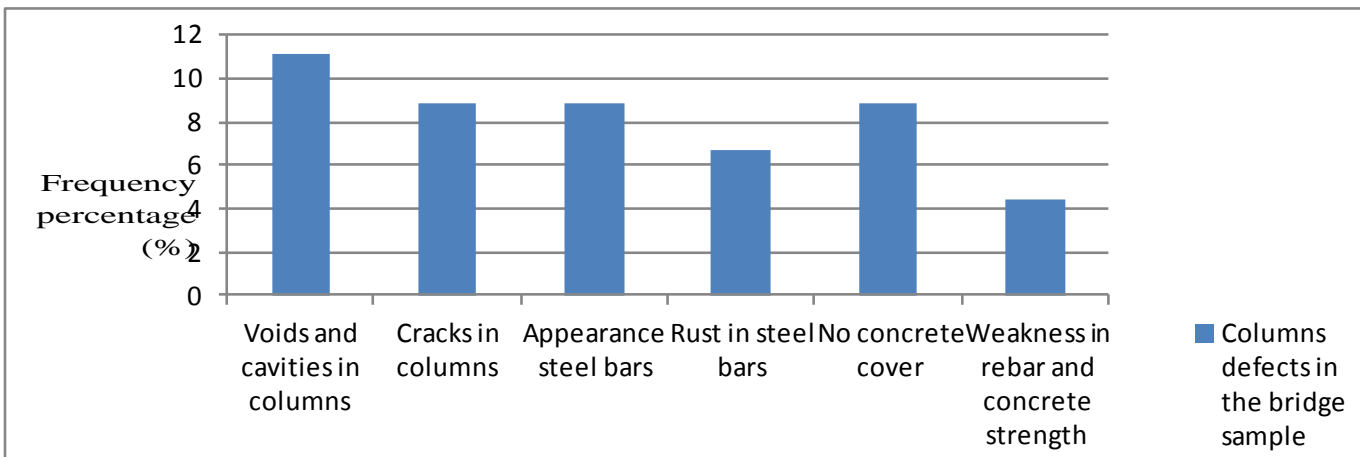

Joints defects detailed in Table [5] and Chart [7]. The defects of joints in the sample were no expansion joints in six bridges and poor status in four bridges.

Table [5] Joints defects in the bridges sample

\begin{tabular}{|l|l|l|}
\hline S.N. & Defect Type & $\begin{array}{l}\text { Frequency } \\
\text { percentage } \\
(\%)\end{array}$ \\
\hline 1 & No expansion joint & 13.35 \\
\hline 2 & Poor state of expansion joints & 8.89 \\
\hline
\end{tabular}

Chart [7] Joints defects in the bridge sample

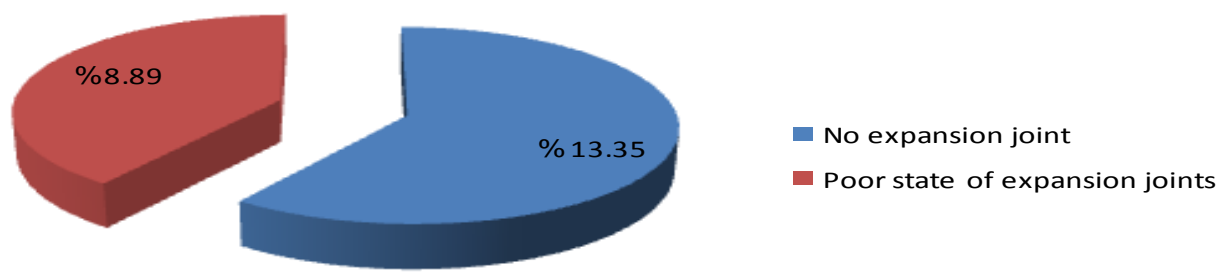


Walkway and handrails defects will be detailed in Table [6]. The majority of defects in walkways and handrails are rust in handrail and disappear many parts of handrail. That will cause rust in the steel bars and on long term will decrease the strength of the reinforced concrete cross section. The lowest defects were Failure in handrail beams and poor condition of the middle island.

Table [6] Walkway and handrails defects in the bridges sample

\begin{tabular}{|l|l|l|}
\hline S.N. & Defect Type & $\begin{array}{l}\text { Frequency } \\
\text { percentage } \\
(\%)\end{array}$ \\
\hline 1 & Poor State of walkway & 28.89 \\
\hline 2 & No walkway & 15.56 \\
\hline 3 & Failure in handrail beams & 2.22 \\
\hline 4 & Poor state of handrail beam and rust in rebar & 31.11 \\
\hline 5 & Failure in walkway and handrail & 15.56 \\
\hline 6 & Disappear many parts of handrails & 37.78 \\
\hline 7 & Rust in handrail & 37.78 \\
\hline 8 & Poor condition of the middle island & 11.11 \\
\hline
\end{tabular}

Supports and cladding defects will be detailed in Table [7] and Chart [8]. The majority of defects is cladding failure at bridge entrance and should be noticed during construction phase well. The minor defect is accumulation of dust and this required periodical follow up.

Table [7] Supports and cladding defects in the bridges sample

\begin{tabular}{|l|l|l|}
\hline S.N. & Defect Type & $\begin{array}{l}\text { Frequency } \\
\text { percentage } \\
(\%)\end{array}$ \\
\hline 1 & Poor state of the cladding & 11.11 \\
\hline 2 & Cladding failure at bridge entrance & 13.33 \\
\hline 3 & Rust in supports & 8.89 \\
\hline 4 & Accumulation of dust & 4.44 \\
\hline
\end{tabular}

Transaction slab defects will be detailed in Table [8] Chart [9]. The majority of defects is poor state for the transaction slab bridge entrance and should be noticed during construction phase well. The minor defect is settlement for the transaction slab and leak of backfilling within it.

Chart [8] Supports and cladding defects in the bridge sample

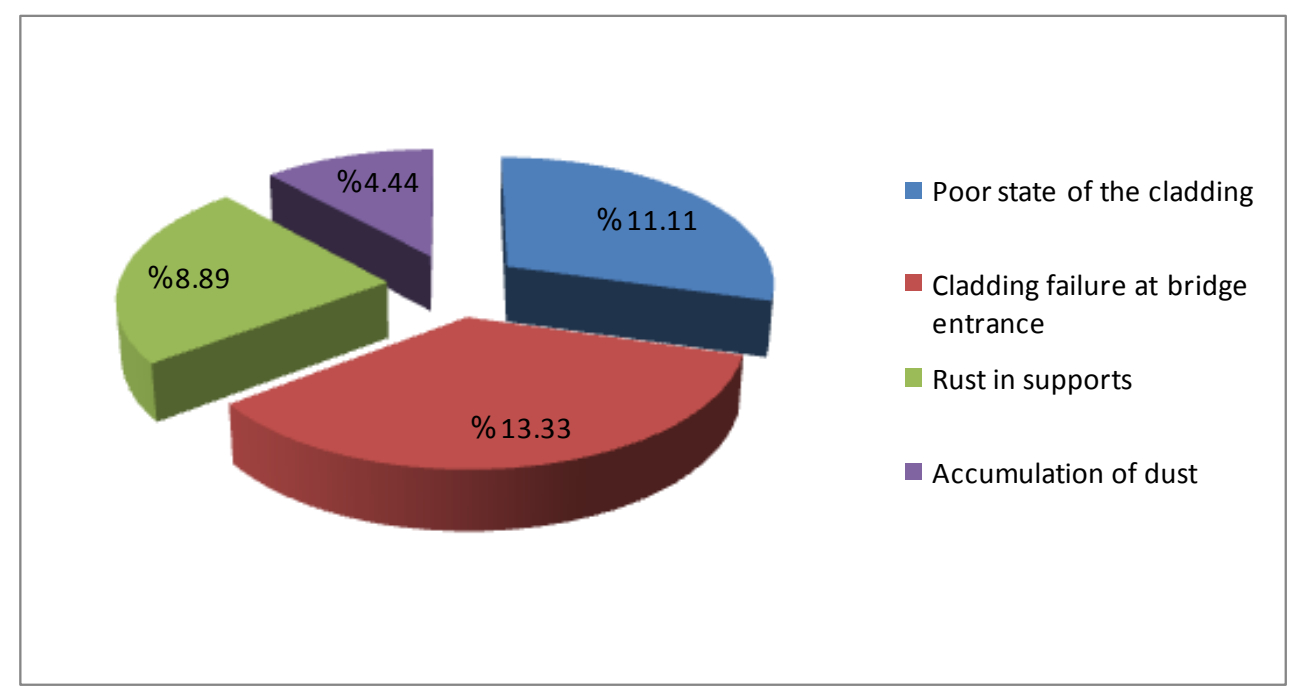


Table [8] Transaction slab defects in the bridges sample

\begin{tabular}{|l|l|l|}
\hline S.N. & Defect Type & $\begin{array}{l}\text { Frequency } \\
\text { percentage } \\
(\%)\end{array}$ \\
\hline 1 & Transaction slab settlement & 2.22 \\
\hline 2 & Backfill leak from within & 2.22 \\
\hline 3 & Poor state of entrance & 6.67 \\
\hline
\end{tabular}

Chart [9] Transaction slab defects in the bridge sample

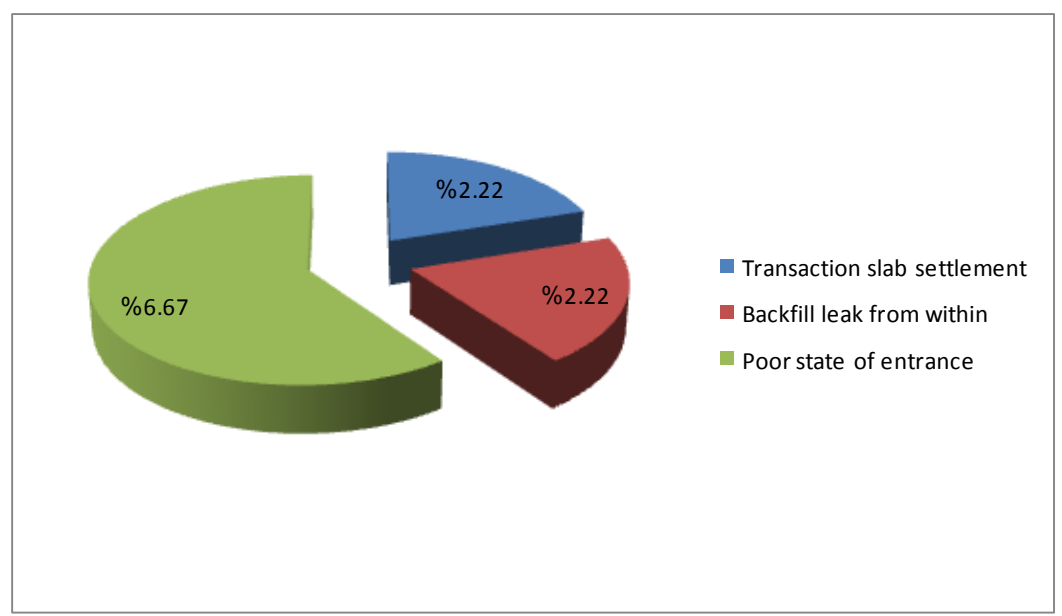

\section{4- MAINTENANCE STRATEGIES}

Maintenance strategies include (nothing to maintain) that is concerned no maintenance at all till the repair become essential. Also the management of the bridge network should be performed at two different level, the routine maintenance level and the level at which a defect or the problem to be a medium to great importance of a structural or functional nature is detected.

\section{5- CONCLUSION}

It was noticed that bridge elements that have large and minor percentage of defects are slabs $(22 \%)$ and cladding (5\%). The main defects in slabs are Voids and cavities in slabs, Appearance steel bars in the slabs and No concrete cover.

It was noticed that main reasons that lead to the mentioned status are no available maintenance database, routine maintenance need to be more effective, trucks maximum axial load should be according to the accepted limits and also it should be used bridge management systems in order to provide data base with every bridge and its maintenance history.

\section{6- RECOMMENDATION}

It is recommended to overcome the bridge problems to maintain suitable Bridge Management System in Egypt taking into consideration the current status of the bridges and the maintenance. Also it is recommended to prepare and apply questionnaire to collect the required parameters that should be included to the Bridge Management System in Egypt.

\section{REFERENCES}

[1] Cheng, M. Y. and Hoang, N.D. "Risk score inference for bridge maintenance project using Evolutionary fuzzy least squares support vector machine", Journal Comp. civil Eng., 2012, 10.1061 / (ASCE) CP. 1943-5487. 0000275, 04014003.

[2] Das, P.C. "Priorization of bridge maintenance needs" Case studies in optimal design and maintenance planning of civil infrastructure systems, D.M. Frangopol, ed., ASCE, Reston, Virginia, 1999, PP. 26-44 
[3] Yang, T., Hsieh, M.Y., and Kung, O.L., "Parallel computing platform for multi objective simulation optimization of bridge maintenance planning", J. Constr. Rng. Manage., (2012) 138 (2), PP. 215-226.

[4] Shan, D. and Li, Q. "Development of a smart-client based bridge management and maintenance system for existing highway bridges", International conference on Transportation Eng., 2009, PP. 3694-3699

[5] Lin, M. and Frangopol, D.M. "Balanacing connectivity of deterioration bridge networks and longterm maintenance cost through optimization "Journal Bridge Eng., 10 (4), 2005, PP.468-441

[6] Elag, Tahas and Wang, Y.M., "Risk assessment for bridge maintenance project: Neural networks versus regression techniques." J. Compu. Civ. Eng., 2007, 21 (6), 402-409

[7] General Authority for Roads \& Bridges and Transportation in Egypt

[8] www.surveysystem.com/sample-size-formula \& www.surveymonkey.com/mp/sample-sizecalculator 